\title{
Curriculum Restructuring and Job Creation Among Nigerian Graduates: The Mediating Role of Emerging Internet Applications
}

\author{
Valentine Joseph Owan $^{1 *}$, Daniel Clement Agurokpon ${ }^{2}$, Joseph Udida Udida ${ }^{3}$ \\ ${ }^{1}$ Department of Educational Foundations, University of Calabar, Calabar-Nigeria. \\ ${ }^{2}$ Department of Microbiology, University of Cross River State, Nigeria \\ ${ }^{3}$ Department of Educational Management, University of Calabar, Calabar-Nigeria. \\ * Corresponding author \\ Email: owanvalentine@gmail.com
}

\begin{abstract}
Existing literature on entrepreneurship education has continually highlighted its potential for job creation. However, much attention has not been paid to the restructuring of the curriculum that can enable entrepreneurship education to thrive for job creation. This study used a structural equation modelling approach to understand the mediating role that the deployment of emerging Internet Applications (IAs) play in the nexus between curriculum restructuring and job creation. Being a quantitative study, a virtual snowball sample of 4,628 higher education graduates (males $=2,362$; females $=2,266$ ) participated in an electronic survey that was designed by the researchers. Results indicate that curriculum restructuring has a substantial link with the deployment of emerging Internet Applications and job creation respectively. The deployment of emerging Internet applications substantially contributes to the job creation activities of Nigerian graduates. There is a significant positive mediation effect of the deployment of emerging Internet applications on the link between curriculum restructuring and job creation by Nigerian graduates. Based on these results practical implications are discussed, while it was concluded that curriculum restructuring and the deployment of emerging Internet applications are very important variables for job creation.
\end{abstract}

Keywords: Curriculum reengineering, entrepreneurship, Internet, unemployment, vocational skills. 


\section{Introduction}

The primary goal of education is the holistic development of a person. It is a source of its evident advantages for living a richer and happier life. Education has the potential to improve society as a whole (Bassey et al., 2011; Ukpor, et al., 2012). It fosters a society in which individuals are aware of their rights and responsibilities. Education is both a cultural and a learning experience (Hill et al., 2020). This allows all individuals to develop cognitive and physical talents, as well as build values and beliefs. The goal of curriculum development is to enhance the district's educational offerings, as well as its instructional activities and practices, to boost student participation in the learning process and student accomplishment (Althauser, 2015; Aydin, 2012). In this regard, job creation has been and has over time, caught the attention of bodies involved in curriculum development.

It has been established that the curriculum of universities in Nigeria has put in efforts in job creation through the restructuring of curriculum to include entrepreneurial and vocational skills. These skills have been shown to help students overcome the issue of job unemployment and sustain the lives of many citizens (Gamede \& Uleanya, 2019; Hahn, 2020; Nabi et al., 2017). Unlike when the perception of individuals was to acquire knowledge and accumulate certificates to work for highly paid and/or white-collar jobs, many people in this era tend to acquire the certificates and look for a way of creating jobs for life substance (Rasit \& Tahar, 2018). With the economic situation of the country where thousands of graduates are being graduated annually, the issue of unemployment continues to reiterate (Ayoade, 2016; Ekong \& Ekong, 2016), this, in addition to graduates working outside their discipline is highly worrisome.

In recent times, the design of university curriculum to incorporate entrepreneur skills is to relieve the pressure of unemployment on the government, through graduate job creation. Many university graduates with positive affluents towards these skills end up setting-up big 
companies that eventually employ others. In this way, the curriculum can fill some unemployment lapses. Before the incorporation of entrepreneurship and vocational skills, other strategies were devised to acquaint undergraduates in their disciple through an internship, industrial training, as well as teaching practice. Studies have shown that these approaches increase the chances of graduates' employability through companies'/schools' recommendations (Agetue \& Nnamdi, 2017; Malgas et al., 2017; Manabete \& Umar, 2018; Okolie et al., 2021; Oyedele, 2018; Zreen et al., 2019). However, Graduate job creation through this means is not common, because the students rather seek employment from the organisations. Furthermore, a recent study found that there is a low extent in the reengineering of curriculum by most higher education institutions (Owan et al., 2021). Reengineering the school curriculum may help promote students' use of emerging technologies for job creation.

Between 2016 and 2021, available evidence suggests that 41.70 percent of all graduates in Nigeria generated at least one job, despite the fact that 58.30 percent of all graduates have not done so (Owan, et al., 2021). This indicates that there is a low rate of job creation among graduates despite the introduction of entrepreneurship education. To add to this, Owan et al. discovered that 58.96 percent of the graduates that own Small and Medium Enterprises had not employed any worker, while 41.04 percent have hired at least one employee from 2016 to 2021. Using a new methodology, the job creation index of the graduates was calculated to be about 50\% (Owan et al., 2021). It has since been argued that with technological innovation, job creation and unemployment should increase and decrease respectively (Balsmeier \& Woerter, 2019; Choi \& Kang, 2019; Kianian et al., 2015; Mortensen \& Pissarides, 1998; Van Roy et al., 2018). This is due to the way technology is encroaching every aspect of life (Odigwe \& Owan, 2020; Owan \& Asuquo, 2021).

Sadly, it has been reported a study that there is a widespread lack of interest in new web-based technologies among Nigerian university students (Owan et al., 2021). The cited 
source provided further empirical evidence that so many of Nigerian tertiary school graduates utilize emerging technologies for word processing, graphics and data science; yet, just a handful of graduates employ them for activities like printing, YouTube video creation and the design of online courses. This downtrend is quite surprising given the important that various Internet applications (IAs) play for income generation.

IAs used to get, share, and display data from respective server systems (Yang et al., 2016). They are accessible exclusively over the internet and are completely inoperable without it. Among these applications are electronic device-based, digital technology-based, industrial internet-based, smartphone-based, smart home-based, smart grid-based, and smart city-based. The use of IAs enhances and enriches the educational process for students since smartphones are becoming students' living standards (Hussein \& Nätterdal, 2015). Again, since the process of learning is a huge task for students, adopting IAs which is a part of their life would motivate them, thus fostering more academic and societal success. This study is therefore centred on curriculum restructuring for job creation through the use of IAs among Nigerian Graduates. The study focuses on three areas including curriculum restructuring, DEIAs and job creation among graduates.

According to Mbanefo and Ebokab (2017), there are a lot of skills that are needed in science education for job creation, teachers are necessary to employ practical techniques in educating pupils, and many issues pose barriers to the acquisition of entrepreneurship skills in basic science education. Restructuring the curriculum as a way of enhancing students' skills would hence be appreciable in the community. Different studies have found that restructuring of curriculum to perk with the current development in the area enhance job creation. Though most studies have been centred on including entrepreneurship studies in the curriculum. (Andrade et al., 2018; Decker et al., 2014; Ferrier, 2013; Kim et al., 2018; Maina, 2014; Mehari \& Belay, 2017; Obi \& Okekeokosisi, 2018; Ozofor \& Ozomadu, 2018; Rankhumise et al., 
2020; Rey-Martí et al., 2016). A study in electrical/electronic engineering found that students' opportunities towards self-reliance are limited because the electrical installation has got less attention in their curriculum (Okafor \& Nwabueze, 2019).

Studies on curriculum restructuring and deployment of emerging IAs appear to be scarce in the literature. This implies that the present study is the first, or among the first kickstarting studies integrating curriculum restructuring and job creation among Nigerian tertiary institution graduates through the use of emerging IAs. Having carried out a thorough search of the literature using internet search engines and sites, the researchers can say that at the time of carrying out this study, no previous studies on emerging IAs and curriculum restructuring exist. The closest studies were focused on Information Communication Technology (ICT) and educational achievement, self-efficacy, job creation, and so on (Dobber et al., 2017; Kaware \& Sain, 2015; Khanna \& Mehrotra, 2019; Lu et al., 2015; Raju et al., 2016; Ratheeswari, 2018; Rohatgi et al., 2016; Tchamyou et al., 2019). For instance, Raju et al. (2016) found that ICT promotes the achievement of educational objectives.

Based on the paucity of research concerning the areas considered in this study, the present study is of utmost importance since it may bridge the gap in the literature. The study would be relevant to the curriculum developing bodies of higher institutions because it may reveal the usefulness of restructuring the curriculum to create job opportunities through the use of emerging IAs. The study would also be important to lecturers and students because it may interest them to start adopting/embracing IAs in teaching and learning. The central aim of the study was to investigate the contribution of curriculum restructuring to job creation through the use of emerging IAs. 


\section{Research question}

The following research questions were framed to guide the study.

i. To what extent has curriculum restructuring (CR) contributed to the job creation (JC) activities of university graduates?

ii. To what extent does the deployment of emerging Internet applications (IAs) contribute to the job creation activities of university graduates?

iii. How much contribution has curriculum restructuring (CR) to the deployment of emerging IAs among university graduates?

\section{Methodology}

This research employed quantitative approaches to collect data via an in-depth survey. The study covered all Nigerian tertiary institution graduates who received their degrees between 2016 and 2021 and are eligible for or exempt from national youth service. This population was chosen for three reasons: first, they graduated during a period when certain curriculum reforms were implemented in Nigeria's tertiary institutions; second, a plethora of highly sophisticated technologies emerged, particularly in the areas of programming, artificial intelligence, and machine learning; and third, the internet underwent several revolutions, gradually phasing out or modifying some outdated systems. The virtual snowball technique was used in the study in obtaining an accidental sample of respondents, the researchers were unaware of the population standard deviation.

An electronic questionnaire tagged "Curriculum Restructuring, Deployment of Emerging Internet Applications, and Job Creation Questionnaire (CRDEIAJCQ) was used for data collection (see https://forms.gle/76geZ6wiqdNJdH6P9). The researchers created the instrument using Google Forms and divided it into five sections. The first section featured a lengthy letter outlining the study's goals, participants, estimated completion dates, and informed consent. Section 2 was created to collect respondents' biographical information 
(gender, age, marital status, university attended, year of graduation, and NYSC service information). Section 3 has 13 elements that evaluate curricular restructuring techniques. The items in section 3 were all structured on a four-point Likert scale, with answer possibilities ranging from Strongly Agree to Strongly Disagree. The first portion of section 4 consisted of a 16-item rating scale asking respondents to score their use of new technology for different objectives. The answer options ranged from 0 (no acquisition) to 4 (complete acquisition) (very high extent of acquisition). The second portion of section 4 consisted of a 16 -item checklist for respondents to mark off what they do use new technology. Graduates' job creation activities were measured in Section 5 of the instrument, which included questions like current employment status, current employer, number of persons employed (for self-employed graduates), and the total number of small and medium-sized firms (SMEs) owned.

Even though the researchers developed the instrument, it was evaluated by six specialists (three of Economics of Education; three of Research, Measurement and Evaluation). After a trial test on 30 final year students at a public institution, the Cronbach alpha technique was used to establish the internal consistency of sections 3 and 4 of the instruments for dependability. The trial exam was conducted on 30 final year students who had finished the same higher education program as those who would be studied in the main research. Curriculum restructuring and the acquisition of new technologies both had reliability estimates of .83 and .91 , respectively. Due to the nature of the goods, no reliability study was performed for job creation.

The researchers used a snowball strategy to gather data for this investigation. The researchers began collecting data by sending the link to the questionnaire to graduates who fit the criteria for selection through email, WhatsApp, Facebook, and Telegram groups. These respondents were encouraged to participate willingly and to share the link to the questionnaire with additional friends, family, and/or neighbours who fulfilled the previously mentioned 
inclusion criteria, as well as to instruct those targeted peers to share the link with others. The link to the questionnaire was shared and distributed consecutively. A moderating factor (year of graduation) was added to section 2 to eliminate any bias and guarantee that answers were obtained from respondents who met the inclusion criteria. The computerized poll garnered a total of 4,874 replies throughout the country after four months of launch and snowballing. The data was cleaned, converted, and recoded, with 246 replies from participants who did not match the participation requirements being eliminated. As a result, 4,628 replies matched the requirements for data analysis.

The respondents of this study are $51 \%$ males $(n=2362)$ and $49 \%$ females $(n=2266)$. The age distribution shows that $18.9 \%$ of the respondents of this study $(n=876)$ are less than 25 years; $21.1 \%(\mathrm{n}=976)$ are between 25 and 29 years; $20.4 \%$ are between 30 and 34 years $(\mathrm{n}$ $=943) ; 19.7 \%$ are between 35 and 39 years $(n=912)$; while those 40 years or older constitute $19.9 \%$ of the study's participants $(n=921)$. Regarding marital status, the analysis of respondents' demographic information shows that $65.4 \%$ of the respondents $(n=3,026)$ are single, $33.41 \%(n=1546)$ are married, $0.9 \%(n=41)$ are divorced, while $0.3 \%(n=15)$ are separated from their partners. Regarding year of graduation, 9.5\% $(n=439), 10.1 \%(n=467)$, $9.7 \%(n=447), 9.9 \%(n=457), 9.6 \%(n=446), 10.6 \%(n=492), 10.5 \%(n=488), 10.2 \%(n$ $=471), 10 \%(n=465)$, and $9.9 \%(n=456)$ of the respondents graduated in 2011, 2012, 2013 , 2014, 2015, 2016, 2017, 2018, 2019, and 2020 respectively. Regarding the National service status, the result of the analysis revealed that $90.5 \%(\mathrm{n}=4,188)$ have completed their service with the NYSC; while $9.5 \%$ of the respondents $(n=440)$ were currently serving. In terms service year, the result indicated that $19.5 \%(\mathrm{n}=901), 18.6 \%(\mathrm{n}=859), 17.3 \%(\mathrm{n}=802)$, $17.9 \%(n=828)$, and $17.3 \%(n=799)$ of the respondents completed their NYSC service in year 2016, 2017, 2018, 2019 and 2020 respectively, while $9.5 \%$ of the respondents serving in 2021. 


\section{Model specification}

The SEM for the mediation model of this study is specified in Fig. 1.

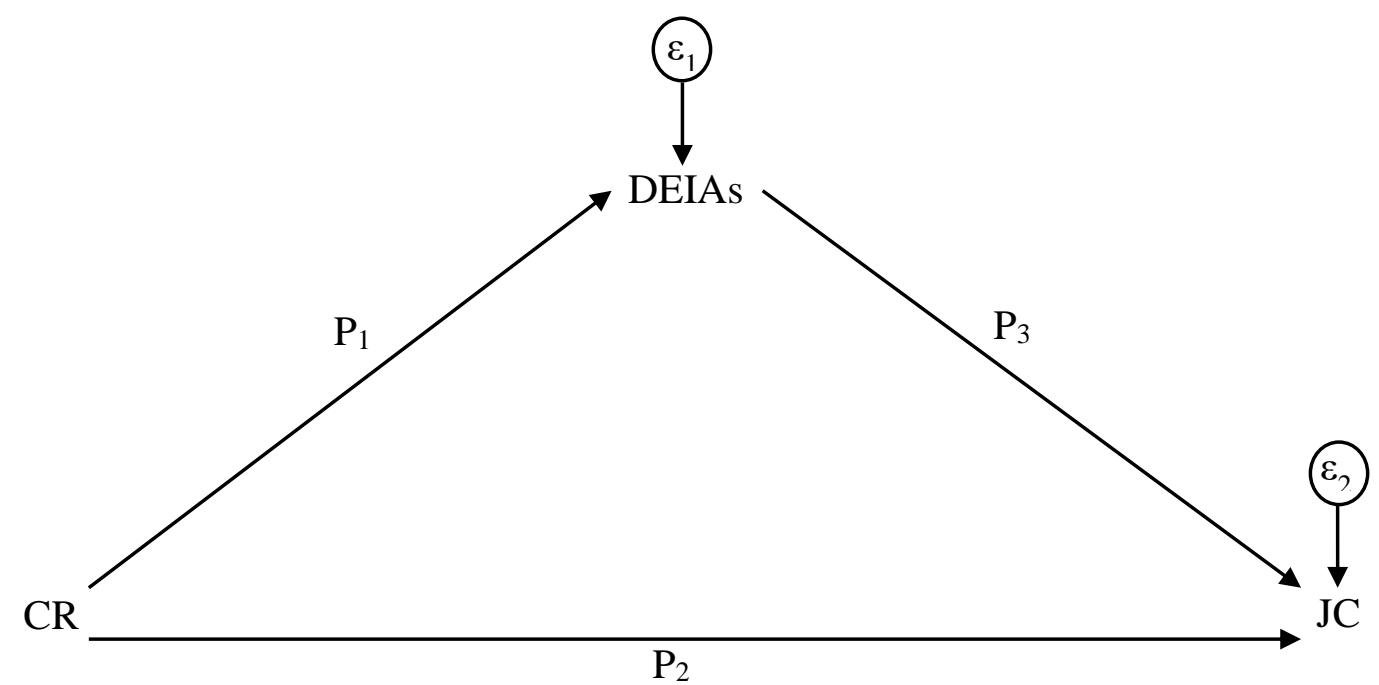

Fig. 1. One-factor mediation model showing causal relationships among the variables

From Fig. 1, the specific linear models were derived as follows:

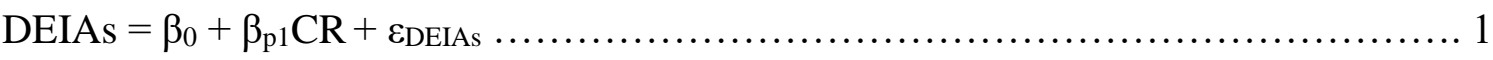

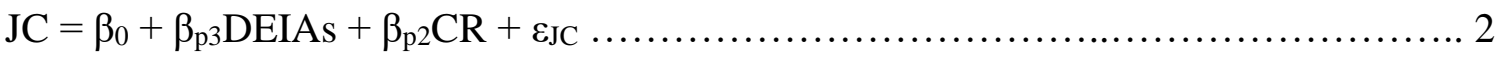

Where:

$\mathrm{M}=$ the mediator variable (Adoptiopn of emerging Internet applications [DEIAs])

$\mathrm{Y}=$ the endogenous variable $(\mathrm{Job}$ creation $[\mathrm{JC}])$

$\mathrm{X}=$ the exogenous variable (Curriculum restructuring $[\mathrm{CR}]$ )

$\beta_{0}=$ the intercept or constant term;

$\beta_{\mathrm{p} 1}-\beta_{\mathrm{p} 3}=$ the standardized regression weights of the partial effects of CR and DEIAs in the model;

$\varepsilon=$ The error term associated with outcome variables DEIAs and JC 


\section{Results}

Research question 1

To what extent has curriculum restructuring (CR) contributed to the job creation (JC) activities of university graduates? The result of simple linear regression analysis in Table 1 shows that CR has a contribution of $92 \%$ to the total variance in the JC activities of Nigerian graduates. The result implies that $8 \%$ of the unaccounted portion of the variance is attributable to other explanatory variables not included in the model. Further evidence in Table 1 shows that the amount of variance in the JC activities of graduates, explained by $\mathrm{CR}$ is statistically significant $\left(\mathrm{F}_{[1,4625]}=52057, \mathrm{p}<.05\right.$. By implication, the adjusted $\mathrm{R}$ squared value of .918 earlier reported, was not a product of chance. It was predicted in Table 1 that a $1 \%$ increase in the restructuring of the curriculum is connected with a $0.25 \%$ increase in the job creation activities of university graduates, so long as other variables remain constant.

Table 1: Simple linear regression analysis of the contribution of CR to the JC activities of university graduates

\begin{tabular}{lllllll}
\hline $\mathrm{R}$ & $\mathrm{R}^{2}$ & Adj. $\mathrm{R}^{2}$ & $\mathrm{SE}$ & $\mathrm{B}$ & $\mathrm{B}$ & $\mathrm{t}$ \\
\hline .96 & .92 & .92 & .62 & .25 & .958 & 228.16 \\
Source & $\mathrm{SS}$ & $\mathrm{Df}$ & $\mathrm{MS}$ & $\mathrm{F}$ & $\mathrm{P}$ & \\
Regression & 19926.20 & 1 & 19926.2 & 52057.55 & .000 & \\
Residual & 1770.32 & 4625 & 0.383 & & & \\
Total & 21696.52 & 4626 & & & & \\
\hline
\end{tabular}

Research question 2

To what extent does the deployment of emerging Internet applications (DEIAs) contribute to the job creation (JC) activities of university graduates? A simple linear regression analysis was performed to answer this research question. As shown in Table 2, result the DEIAs explained $69 \%$ of the total variance in the JC activities of Nigerian graduates. By implication, 
other extraneous variables not included in the model may account for the remaining $31 \%$ of the unexplained variance. The ANOVA result in Table 2 further revealed that the contribution made by the DEIAs to the JC activities of university graduates is statistically significant $\left(\mathrm{F}_{[1}\right.$, $4625]=10210.83, \mathrm{p}<.05)$. By prediction, Table 2 revealed that as long as other variables remain unchanged, a $1 \%$ increase in the DEIAs will lead to a $0.19 \%$ increase in the job creation activities of university graduates.

Table 2: Simple linear regression analysis of the contribution of the DEIAs to the JC activities of university graduates

\begin{tabular}{llllll}
\hline $\mathrm{R}$ & $\mathrm{R}^{2}$ & Adj. $\mathrm{R}^{2}$ & $\mathrm{SE}$ & $\mathrm{B}$ & $\mathrm{T}$ \\
\hline .83 & .69 & .69 & 1.21 & .19 & 101.05 \\
Source & $\mathrm{SS}$ & $\mathrm{Df}$ & $\mathrm{MS}$ & $\mathrm{F}$ & p-value \\
Regression & 14932.74 & 1 & 14932.74 & 10210.83 & .00 \\
Residual & 6763.79 & 4625 & 1.462 & & \\
Total & 21696.52 & 4626 & & & \\
\hline
\end{tabular}

Research question 3

How much contribution has curriculum restructuring (CR) to the deployment of emerging Internet applications (DEIAs) among university graduates? The result of the analysis using simple linear regression analysis (see table Table 3) shows that $74 \%$ of the total variance in the DEIAs is accounted for by CR. This result suggests that $26 \%$ of the unexplained portion of the variance is attributable to other predictor variables not enlisted in the model. The ANOVA section of Table 3 proved that the contribution of CR to the DEIAs is statistically significant $\left(\mathrm{F}_{[1,4625]}=12979.31, \mathrm{p}<.05\right)$. The prediction in Table 3 is that a $1 \%$ increase in curriculum restructuring is connected with a $0.94 \%$ increase in the deployment of DEIAs, other things being equal. 
Table 3: Simple linear regression analysis of the contribution of CR to the DEIAs among university graduates

\begin{tabular}{llllll}
\hline $\mathrm{R}$ & $\mathrm{R}^{2}$ & Adj. $\mathrm{R}^{2}$ & $\mathrm{SE}$ & $\mathrm{B}$ & $\mathrm{t}$ \\
\hline .86 & .74 & .74 & 4.77 & .94 & 113.93 \\
Source & $\mathrm{SS}$ & $\mathrm{Df}$ & $\mathrm{MS}$ & $\mathrm{F}$ & $\mathrm{p}$-value \\
Regression & 294823.5 & 1 & 294823.5 & 12979.31 & .00 \\
Residual & 105056.3 & 4625 & 22.72 & & \\
Total & 399879.8 & 4626 & & & \\
\hline
\end{tabular}

Research question 4

To what extent does the deployment of emerging Internet applications (DEIAs) mediate the nexus between curriculum restructuring (CR) and job creation (JC)? To answer this research question, the standardized total, direct and indirect effects of a structural equation modelling approach was used (See Fig. 2). The result of our analysis revealed that CR has a standardized total effect of $\beta=.958$ on JC activities of graduates. Out of this effect, $\beta=.936$ is direct and $\beta=.022$ is indirect. This implies that the indirect effect of .022 is due to the mediation of the DEIAs. To test for the statistical significance of the mediation effect, the results from Haye's PROCESS macro revealed that the mediation effect of DEIAs on the link between CR and JC $(\beta=.0220)$ falls within the lower and upper limits of the bootstrapped confidence intervals -.0057 and .0503 , with a bootstrapped standard error of .014 . This implies that the mediation of DEIAs on the nexus between CR and JC is significantly different from zero. Therefore, DEIAs positively and significantly mediate the association between CR and JC.

Based on these results, the following equations are fitted:

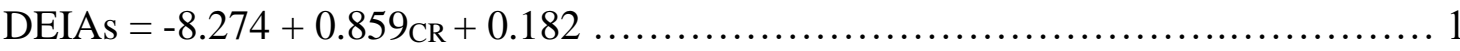

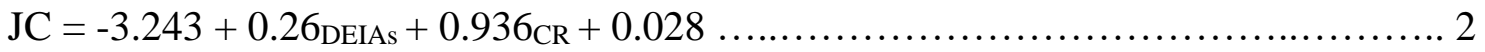




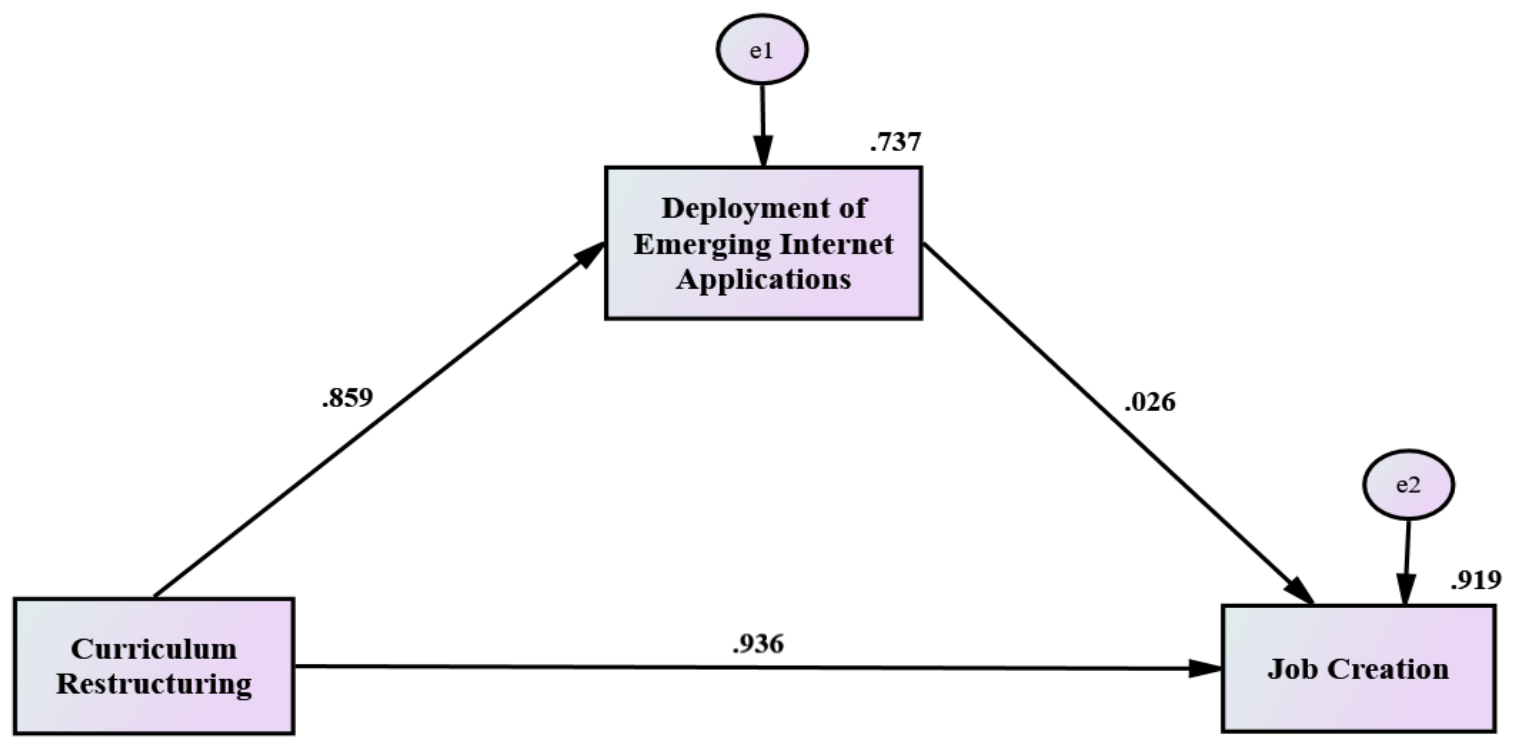

Fig. 2: Fitted one-factor mediator model showing the mediation of DEIAs on the nexus between $\mathrm{CR}$ and JC

\section{Discussion}

This study was designed to inter-link curriculum restructuring (CR), deployment of merging technologies (DEIAs) and job creation (JC) among Nigerian higher education graduates. The quantitative research method was used with primary data collected from an electronic survey. Our analysis proved that curriculum restructuring has a substantial link with the deployment of emerging IAs and job creation respectively. This result implies that when the curriculum of the educational system is reengineered, Nigerian graduates are more likely to adopt current technologies for various purposes and create jobs. This implies further that the restructuring of the school curriculum may reduce unemployment in Nigeria. The result is explainable because the restructuring of the curriculum may lead to schools offering more STEM-based courses and those that meet the current needs of Nigerian society. The curriculum implementation phase may also allow for lesson contents and learning experiences that are skill-based to be offered. The acquisition of skills and competencies are the requirements for the effective use of technological products and job creation. This result aligns with the position of other studies that the introduction of entrepreneurship programmes to the school curriculum 
increases the chances of graduates' employability through job creation (Agetue \& Nnamdi, 2017; Manabete \& Umar, 2018; Okolie et al., 2021; Zreen et al., 2019).

It was also confirmed in this study that the deployment of emerging Internet applications substantially contributes to the job creation activities of Nigerian graduates. The finding implies that a high rate of job creation is connected to a high rate of deployment of emerging IAs. Thus, graduates that can utilize emerging Internet applications are more likely to create jobs than those that do not. The result should not be a surprise because many firms are constantly in search of manpower with the capacity to utilize state-of-the-art devices for work performance. Possessing the ability to manipulate such devices may enable graduates to grab such opportunities rather than firms seeking skilled personnel from overseas. Furthermore, experience has shown that many jobs have been created by skilled personnel through training initiatives. This suggests that graduates with the capacity to utilize emerging IAs may start earning from teaching others how to use the same or similar technologies. This result corroborates the finding of Mbanefo and Ebokab (2017) that there are a lot of skills that are needed in science education for job creation; thus, teachers need to employ practical techniques in educating learners to acquire such skills.

Lastly, the current study established a significant positive mediation effect of the deployment of emerging Internet applications on the link between curriculum restructuring and job creation by Nigerian graduates. This result implies that the effect of curriculum restructuring on job creation (earlier discussed) can be strengthened significantly if students adopt emerging IAs. This finding suggests that graduates of a reengineered curriculum that adopt emerging IAs are more likely to create jobs than their colleagues that do not adopt emerging Internet applications. The boost that curriculum engineering receives from the deployment of emerging IAs to push job creation activities further is due to the diverse perspectives DEIAs brings. While the restructuring of the curriculum will equip learners with 
the needed skills, DEIAs provides a platform for them to practice or demonstrate such skills for useful purposes.

\section{Conclusion}

The conclusion reached in this study is that curriculum restructuring and the deployment of emerging Internet applications are very important variables for job creation. Curriculum restructuring offers students the opportunity to acquire relevant skills for effective functioning in contemporary society. However, the deployment of emerging IAs provides them with the opportunity to make meaningful use of such skills. Although both CR and DEIAs can function independently for graduates to create jobs, job creation chances are higher when both variables are jointly practised. Therefore, efforts must be made by all stakeholders to reengineer the higher education curriculum for future job creation among graduates. Graduates must ensure that the latest technologies across different fields are adopted for increased job creation in Nigeria.

\section{References}

Agetue, F. U., \& Nnamdi, A. E. (2017). Entrepreneurship training: A tool for job creation and sustainable national development, Nigeria. Journal of Teacher Perspective (JOFEP), 5(3), 475-482. https://cutt.ly/wTtq2Lz

Althauser, K. (2015). Job-embedded professional development: Its impact on teacher selfefficacy and student performance. Teacher Development, 19(2), 210-225. https://doi.org/10.1080/13664530.2015.1011346

Andrade, A., Chopra, S., Nurlybayev, B., \& Golab, L. (2018). Quantifying the impact of entrepreneurship on cooperative education job creation. International Journal of WorkIntegrated Learning, 19(1), 51-68. https://eric.ed.gov/?id=EJ1179836

Aydin, H. (2012). Multicultural education curriculum development in Turkey. Mediterranean Journal of Social Sciences, 3(3), 277-277. https://cutt.ly/UTtwoEe

Ayoade, E. O. (2016). Employment generation through entrepreneurial development: The Nigerian experience. British Journal of Economics, Management \& Trade, 11(3), 1-14. https://doi.org/10.9734/BJEMT/2016/21740 
Balsmeier, B., \& Woerter, M. (2019). Is this time different? How digitalization influences job creation and destruction. Research Policy, 48(8), Article 103765. https://doi.org/10.1016/j.respol.2019.03.010

Bassey, P. U., Bisong, N., Isangedighi, A. J., \& Ubi, I. O. (2011). Job Performance Effectiveness: A Comparison of Teachers in Public and Private Schools in Cross River State-Nigeria. Lwati: A Journal of Contemporary Research, 8(2), 9-15.

Choi, D. Y., \& Kang, J. H. (2019). Net job creation in an increasingly autonomous economy: The challenge of a generation. Journal of Management Inquiry, 28(3), 300-305. https://doi.org/10.1177/1056492619827372

Decker, R., Haltiwanger, J., Jarmin, R., \& Miranda, J. (2014). The role of entrepreneurship in US job creation and economic dynamism. Journal of Economic Perspectives, 28(3), 3 24. https://doi.org/10.1257/jep.28.3.3

Dobber, M., Zwart, R., Tanis, M., \& van Oers, B. (2017). Literature review: The role of the teacher in inquiry-based education. Educational Research Review, 22, 194-214. https://doi.org/10.1016/j.edurev.2017.09.002

Ekong, U. M., \& Ekong, C. U. (2016). Skills acquisition and unemployment reduction in Nigeria: A case study of National Directorate of Employment (NDE) in Akwa Ibom State. International Journal of Economics and Management Sciences, 5(4), 1-10. https://doi.org/10.4172/2162-6359.1000352

Ferrier, M. B. (2013). Media entrepreneurship: Curriculum development and faculty perceptions of what students should know. Journalism \& Mass Communication Educator, 68(3), 222-241. https://doi.org/10.1177/1077695813494833

Gamede, B. T., \& Uleanya, C. (2019). Impact of entrepreneurship education on business organisations. Journal of Entrepreneurship Education, 22(2), 1-11. https://cutt.ly/vTtwgbR

Hahn, D., Minola, T., Bosio, G., \& Cassia, L. (2020). The impact of entrepreneurship education on university students' entrepreneurial skills: a family embeddedness perspective. Small Business Economics, 55(1), 257-282. https://doi.org/10.1007/s11187-019-00143-y

Hill, B., Winmar, G., \& Woods, J. (2020). Exploring transformative learning at the cultural interface: Insights from successful Aboriginal university students. The Australian Journal of Indigenous Education, 49(1), 2-13. https://doi.org/10.1017/jie.2018.11

Hussein, M., \& Nätterdal, C. (2015). The benefits of virtual reality in education: A comparison study. University of Gothenburg. https://gupea.ub.gu.se/handle/2077/39977

Kaware, S. S., \& Sain, S. K. (2015). ICT application in education: an overview. International Journal of Multidisciplinary Approach \& Studies, 2(1), 25-32. https://cutt.ly/aTtwc1m

Khanna, R., \& Mehrotra, D. (2019). The roadmap for quality improvement from traditional through competency-based education (CBE) towards outcome-based education (OBE) in dentistry. Journal of Oral Biology and Craniofacial Research, 9(2), 139-142. https://doi.org/10.1016/j.jobcr.2019.02.004 
Kianian, B., Tavassoli, S., \& Larsson, T. C. (2015). The role of additive manufacturing technology in job creation: an exploratory case study of suppliers of additive manufacturing in Sweden. Procedia CIRP, 26, 93-98. https://doi.org/10.1016/j.procir.2014.07.109

Kim, K. C., El Tarabishy, A., \& Bae, Z. T. (2018). Humane entrepreneurship: How focusing on people can drive a new era of wealth and quality job creation in a sustainable world. Journal of Small Business Management, 56, 10-29. https://doi.org/10.1111/jsbm.12431

Lu, C., Tsai, C. C., \& Wu, D. (2015). The role of ICT infrastructure in its application to classrooms: A large scale survey for middle and primary schools in China. Journal of Educational Technology \& Society, 18(2), 249-261. https://cutt.ly/VTtwEf0

Maina, S. (2014). The role of entrepreneurship education on job creation among youths in Nigeria. International Letters of Social and Humanistic Sciences, 4, 87-96. https://doi.org/10.18052/www.scipress.com/ILSHS.15.87

Malgas, B., Khatle, T., \& Mason, R. B. (2017). Job creation in the South African retail sector. The Retail and Marketing Review, 13(1), 1-13. https://cutt.ly/xTtwCXm

Manabete, S. S., \& Umar, B. (2018). Technical and vocational education and training for job creation in Nigeria. International Journal of Business and Administrative Studies, 4(1), 21-30. https://doi.org/10.20469/ijbas.4.10003-1

Mbanefo, M. C., \& Ebokab, O. C. (2017). Acquisition of innovative and entrepreneurial skills in basic science education for job creation in Nigeria. Science Education International, 28(3), 207-213. https://doi.org/10.33828/sei.v28.i3.4

Mehari, A. T., \& Belay, C. F. (2017). Challenges and prospects of entrepreneurship development and job creation for youth unemployed: evidence from Addis Ababa and Dire Dawa city administrations, Ethiopia. Journal of Innovation and Entrepreneurship, 6(1), 1-22. https://doi.org/10.1186/s13731-017-0070-3

Mortensen, D. T., \& Pissarides, C. A. (1998). Technological progress, job creation, and job destruction. Review of Economic dynamics, 1(4), 733-753. https://doi.org/10.1006/redy.1998.0030

Nabi, G., Liñán, F., Fayolle, A., Krueger, N., \& Walmsley, A. (2017). The impact of entrepreneurship education in higher education: A systematic review and research agenda. Academy of Management Learning \& Education, 16(2), 277-299. https://doi.org/10.5465/amle.2015.0026

Obi, M. N., \& Okekeokosisi, J. O. (2018). Extent of implementation of national entrepreneurship curriculum in tertiary institutions as perceived by educators. American Journal of Education and Learning, 3(2), 108-115. https://doi.org/10.20448/804.3.2.108.115

Odigwe, F. N., \& Owan, V. J. (2020). Academic staff personal variables and utilization of ICT resources for research, teaching and records management in higher education. Proceedings of the 8th Annual European Conference on Education (ECE, 2020), 107123. https://doi.org/10.22492/issn.2188-1162.2020.11 
Okafor, I., \& Nwabueze, I. R. (2019). Improving the Curriculum Content of Electrical/Electronics Technology Education in Colleges of Education in Nigeria for Better Job Creation. Multidisciplinary Journal of Education, Research and Development, 3(1). 1-8. https://cutt.ly/dTtw0mv

Okolie, U. C., Nwajiuba, C. A., Eneje, B., Binuomote, M. O., Ehiobuche, C., \& Hack-Polay, D. (2021). A critical perspective on industry involvement in higher education learning: Enhancing graduates' knowledge and skills for job creation in Nigeria. Industry and Higher Education, 35(1), 61-72. https://doi.org/10.1177/0950422220919655

Owan, V. J., \& Asuquo, M. E. (2021). Assessment of socio-demographic factors and students' satisfaction with the study of ICT in secondary schools. Pedagogical Research, 6(3), em0101. https://doi.org/10.29333/pr/11087

Owan, V. J., Udida, J. U., Ekaette, S. O., \& Ekpenyong, J. A. (2021). Extents of curriculum reengineering practices, adoption of emerging web-based technologies and job creation: Perspective of Nigerian graduates. Technology and Resources in Education E-journal, 4(63), Article 3943803. https://doi.org/10.2139/ssrn.3943803

Oyedele, A. F. (2018). Impact of Entrepreneurial Practice on Job Creation: Selected Cases of Metal Scrap Business Operators in Kwara State, Nigeria. PhD Dissertation, (Kwara State University), Nigeria. https://cutt.ly/8Ttw6Xh

Ozofor, N. M., \& Ozomadu, E. A. (2018). Mathematics for entrepreneurship and job creation in Nigeria. International Research Journal of Mathematics, Engineering and IT, 5(8), 513. http://eprints.gouni.edu.ng/2221/

Raju, S. V., Raju, M. B., Abbaiah, G., \& Gudavalli, M. (2016). Role of ICT in outcome-based education. In 2016 IEEE 6th International Conference on Advanced Computing (IACC) (pp. 815-819). IEEE. https://doi.org/10.1109/IACC.2016.155

Rankhumise, E. M., Letsoalo, M. E., \& Nguza-Mduba, B. (2020). Entrepreneurship education's curriculum delivery at two South African universities: students' perspective. Journal of Entrepreneurship Education, 23, 1-16. https://cutt.ly/ZTteoUO

Rasit, N., \& Tahar, M. M. (2018). The Employability Skills Among Vocational School Students in the Final Year of Malaysian Skills Certificate. Jurnal Penelitian dan Pengembangan Pendidikan Luar Biasa, 5(1), 57-61. https://cutt.ly/lTtefOV

Ratheeswari, K. (2018). Information communication technology in education. Journal of Applied and Advanced Research, 3(1), 45-47. https://doi.org/10.21839/jaar.2018.v3iS1.169

Rey-Martí, A., Ribeiro-Soriano, D., \& Sánchez-García, J. L. (2016). Giving back to society: Job creation through social entrepreneurship. Journal of Business Research, 69(6), 20672072. https://doi.org/10.1016/j.jbusres.2015.12.010

Rohatgi, A., Scherer, R., \& Hatlevik, O. E. (2016). The role of ICT self-efficacy for students' ICT use and their achievement in a computer and information literacy test. Computers \& Education, 102, 103-116. https://doi.org/10.1016/j.compedu.2016.08.001 
Tchamyou, V. S., Asongu, S. A., \& Odhiambo, N. M. (2019). The role of ICT in modulating the effect of education and lifelong learning on income inequality and economic growth in Africa. African Development Review, 31(3), 261-274. https://doi.org/10.1111/1467$\underline{8268.12388}$

Ukpor, C. O., Ubi, I. O., \& Okon, A. E. (2012). Assessment of factors determining parents' preference for private secondary schools in rural communities of Cross River State. Global Journal of Educational Research, 11(2), 99-106. https://doi.org/10.4314/gjedr.v11i2.4

Van Roy, V., Vértesy, D., \& Vivarelli, M. (2018). Technology and employment: Mass unemployment or job creation? Empirical evidence from European patenting firms. Research Policy, 47(9), 1762-1776. https://doi.org/10.1016/j.respol.2018.06.008

Yang, Z., Wu, B., Zheng, K., Wang, X., \& Lei, L. (2016). A survey of collaborative filteringbased recommender systems for mobile internet applications. IEEE Access, 4, 32733287. https://doi.org/10.1109/ACCESS.2016.2573314

Zreen, A., Farrukh, M., Nazar, N., \& Khalid, R. (2019). The role of internship and business incubation programs in forming entrepreneurial intentions: an empirical analysis from Pakistan. Central European Management Journal, 27(2), 97-113. https://doi.org/10.7206/jmba.ce.2450-7814.255 